\title{
The effect of lipid emulsion during advanced cardiac life support for Bonzai (Tetrahydrocannabinol) cardiovascular toxicity
}

\author{
Demet Doğan Erol ${ }^{1 *}$, Can Erdoğan ${ }^{1}$, Cem Koray Çataroğlu' ${ }^{1}$, Süleyman Sürer ${ }^{2}$ and Zeynep Uluşan Özkan ${ }^{2}$ \\ ${ }^{1}$ Department of Anaesthesiology and Reanimation, Yıldırım Beyazıt Hospital, Ankara, Turkey \\ ${ }^{2}$ Department of Cardiovascular Surgery, Yıldırım Beyazıt Hospital, Ankara, Turkey
}

\section{Objective}

Worldwide, bonzai tetrahydrocannabinol is among the most widely used illicit drugs. The current wave of decriminalization may lead to more widespread use, and it is important that cardiologists be made aware of the potential for marijuana-associated adverse cardiovascular effects that may begin to occur in the population at a greater frequency. The main active substance, tetrahydrocannabinol, affects cannabinoid receptor 1 in the brain and cannabinoid receptor 2 in the periphery, with predominantly psychoactive effects [1]. There are several wellrecognized complications associated with tetrahydrocannabinol use, including psychiatric, respiratory system, and cardiovascular disorders [2]. Published reports describe a temporal relation between tetrahydrocannabinol use and the development of acute myocardial infarction, cardiomyopathy, and sudden cardiac death. The mechanism underlying the association between tetrahydrocannabinol use and myocardial infarction is currently unknown. It is possible that cannabis has a deleterious effect on coronary microcirculation. Dahdouh, et al. reported the case of a 20 years old patient who abused tobacco and marijuana and developed cardiac arrest and massive myocardial infarction [3].

Lipid resuscitation refers to the use of an intravascular infusion of a lipid emulsion to treat severe, systemic drug toxicity or poisoning. Increasing evidence suggests that the intravenous (IV) infusion of lipid emulsions can reverse the cardiac and neurologic effects of local-anesthetic toxicity [4]. The role of lipid emulsion has expanded to treatment of cardiac toxicity due to other lipophilic drugs. Indeed, case reports support the early use of lipid emulsion at the first sign of arrhythmia, prolonged seizure activity, or rapid progression of toxic manifestations in patients with suspected local anesthetic toxicity. The similarity of several subsequent reports suggests that underlying ischemic heart disease or cardiac conduction defects may predispose to local anesthetic cardiac toxicity [5].

\section{Case report}

23 years old man reported heart fluttering and near syncope a few hours after bonsai tetrahydrocannabinol, heroin smoking. In the emergency department, he was found to have a right bundle-branchtype ventricular tachycardia and had failed more than 40 mins of standard life support therapy including ventilation with oxygen, vasopressors, and force diüuresis. Current guidelines suggest that $20 \%$ lipid emulsion initially be administered as a bolus of $1.5 \mathrm{~mL} / \mathrm{kg}$ over $1 \mathrm{~min}$. Following completion of the bolus, a continuous infusion of $0.25 \mathrm{~mL} / \mathrm{kg} / \mathrm{min}$ should be started. Followed 20\% lipid infusion at 16 hours rapidly restored normal cardiac markers and hemodynamic parameters. The patient recovered completely with no evidence of myocardial damage after 96 hours. (Table 1)

\section{Conclusions}

While the exact mechanism of action is not known, several hypotheses exist as to how lipid emulsion works in the setting of local anesthetic toxicity. The first is the 'lipid sink' hypothesis that suggests that lipid-soluble local anesthetic molecules in the aqueous phase are extracted by the injected lipid. The lipid sequesters the local anesthetic and reduces the concentration of tissue bound local anesthetic. Alternatively, the metabolic hypothesis postulates that lipid impedes local anesthetic's inhibition of acyl carnitine, thereby improving mitochondrial metabolism. Finally, it has been proposed that lipid emulsion increases calcium concentrations in myocytes thereby improving contractility [6].

Table 1. Cardiac markers

\begin{tabular}{|c|c|c|c|c|c|c|c|c|c|}
\hline & $\begin{array}{c}\text { 4. } \\
\text { hour }\end{array}$ & $\begin{array}{c}\mathbf{8 .} \\
\text { hour }\end{array}$ & $\begin{array}{c}\mathbf{1 2 .} \\
\text { hour }\end{array}$ & $\begin{array}{c}\mathbf{1 6 .} \\
\text { hour }\end{array}$ & $\begin{array}{c}\text { 20.hour } \\
\text { After } \\
\text { lipid }\end{array}$ & $\begin{array}{c}\text { 24.hour } \\
\text { After } \\
\text { lipid }\end{array}$ & $\begin{array}{c}\text { 48.hour } \\
\text { After } \\
\text { lipid }\end{array}$ & $\begin{array}{c}\text { 72.hour } \\
\text { After } \\
\text { lipid }\end{array}$ & $\begin{array}{c}\text { 96.hour } \\
\text { After } \\
\text { lipid }\end{array}$ \\
\hline $\begin{array}{c}\text { Creatinin } \\
\text { kinaz } \\
\text { (U/L) }\end{array}$ & 1384 & 2576 & 3137 & 4065 & 2324 & 1215 & 266 & 117 & \\
\hline $\begin{array}{c}\text { CKMB } \\
\text { (U/L) }\end{array}$ & 64 & 78 & 99 & 95 & 55 & 60 & 19 & 22 & 6.6 \\
\hline $\begin{array}{c}\text { Troponin } \\
\text { I(ng/ml) }\end{array}$ & & 1.11 & 1.49 & 2.5 & 0.67 & & 0.08 & 0.05 & 0.03 \\
\hline AST (U/L) & 109 & 161 & 160 & 157 & 115 & 75 & 27 & 33 & 28 \\
\hline ALT (U/L) & 85 & 134 & 138 & 135 & 129 & 105 & 71 & 56 & 48 \\
\hline
\end{tabular}

Correspondence to: Demet Doğan Erol, Department of Anaesthesiology and Reanimation, Yıldırım Beyazıt Hospital, Ankara, Turkey, E-mail: demetdoganerol@mynet.com

Key words: Bonzai, tetrahydrocannabinol, cardiovascular disorders, lipid resuscitation

Received: January 10, 2018; Accepted: January 26, 2018; Published: January 30, 2018 


\section{References}

1. Thomas G, Kloner RA, Rezkalla S (2014) Adverse cardiovascular, cerebrovascular, and peripheral vascular effects of marijuana inhalation: what cardiologists need to know. Am J Cardiol 113: 187-190. [Crossref]

2. Jouanjus E, Leymarie F, Tubery M, Lapeyre-Mestre M (2011) Cannabisrelated hospitalizations: unexpected serious events identified through hospital databases. $\mathrm{Br} \mathrm{J}$ Clin Pharmacol 71: 758-765. [Crossref]

3. Dahdouh Z, Roule V, Lognoné T, Sabatier R, Grollier G (2012) Cannabis and coronary thrombosis: what is the role of platelets? Platelets 23: 243-245. [Crossref]
4. Neal JM, Bernards CM, Butterworth JF $4^{\text {th }}$, Di Gregorio G, Drasner K, et al. (2010) ASRA practice advisory on local anesthetic systemic toxicity. Reg Anesth Pain Med 35: 152-161. [Crossref]

5. Weinberg GL (2010) Treatment of Local Anesthetic Systemic Toxicity (LAST). Reg Anesth Pain Med 35: 188-193. [Crossref]

6. Toledo P (2011) The role of lipid emulsion during advanced cardiac life support for local anesthetic toxicity. Int J Obstet Anesth 20: 60-63. [Crossref]

Copyright: $@ 2018$ Erol DD. This is an open-access article distributed under the terms of the Creative Commons Attribution License, which permits unrestricted use, distribution, and reproduction in any medium, provided the original author and source are credited. 